\title{
Impact of front line demonstration on adoption of berseem fodder production technology by the farmers
}

\author{
BACCHU SINGH AND NAVAB SINGH
}

\begin{abstract}
In this study researchers focused on the extent of adoption of berseem fodder production technology by the farmers. The investigation was concern with Krishi Vigyan Kendra Chittorgarh. The sample included 120 beneficiaries and 120 non-beneficiaries of front line demonstrations on berseem fodder cultivation. The results show that majority of beneficiary and non-beneficiary respondents belonged to age group (27-41 years), herd size (4-10 animals), moderate participation in extension activities (4-7 extension activities), literate upto primary education and possessed small size of land holdings. Majority of the beneficiaries and non-beneficiaries were found to have medium extent of adoption of berseem fodder production technology. Beneficiary respondents possessed maximum adoption regarding "Soil treatment and field preparation" with 83.30 MPS. While, non-beneficiary respondents indicated highest adoption regarding "irrigation management", of berseem fodder production technology with 38.98 MPS. Similarly, they possessed least adoption regarding the "insect and disease management" (1.69 and 2.69 MPS) aspect of barseem fodder cultivation. There was a significant difference in extent adoption of beneficiary and nonbeneficiary farmers with regards to berseem fodder production technology.
\end{abstract}

KEY WORDS : Front line demonstration, Adoption, Berseem fodder production technology, Beneficiary, Non-beneficiary

How TO CITE THIS PAPER : Singh, Bacchu and Singh, Navab (2016). Impact of front line demonstration on adoption of berseem fodder production technology by the farmers. Res. J. Animal Hus. \& Dairy Sci., 7(1) : 1-6 : DOI: 10.15740/HAS/RJAHDS/7.1/1-6.

- MEMBERS OF RESEARCH FORUM

Address for correspondence :

Bacchu Singh, Krishi Vigyan Kendra (A.U.), Borkheda, KOTA (RAJASTHAN) INDIA

Email : bs_meena38@yahoo.com

Associated Authors' :

Navab Singh, Krishi Vigyan Kendra (A.U.), Borkheda, KOTA (RAJASTHAN) INDIA 